\title{
Article \\ Influence of the Modulus of Elasticity of CFRPs on the Compressive Behavior of Confined Test Pieces and on the Flexural Behavior of Short Concrete Beams
}

\author{
Daniela Brizuela Valenzuela ${ }^{1,2}$, María de las Nieves González García ${ }^{1, *(1)}$ and Alfonso Cobo Escamilla ${ }^{3}$ \\ 1 Departamento de Construcciones Arquitectónicas y su Control, Escuela Técnica Superior de Edificación, \\ Universidad Politécnica de Madrid, Av. Juan de Herrera, 6, 28040 Madrid, Spain; \\ daniela.brizuela.valenzuela@alumnos.upm.es \\ 2 Escuela de Ingeniería, Facultad de Ingeniería y Arquitectura, Universidad Central de Chile, Campus Vicente \\ Kovacevic I, Av. Santa Isabel 1186, 8330601 Santiago, Chile \\ 3 Departamento de Tecnología de la Edificación, Escuela Técnica Superior de Edificación, Universidad \\ Politécnica de Madrid, 28040 Madrid, Spain; alfonso.cobo@upm.es \\ * Correspondence: mariadelasnieves.gonzalez@upm.es
}

check for updates

Citation: Brizuela Valenzuela, D.; González García, M.d.1.N.; Cobo

Escamilla, A. Influence of the Modulus of Elasticity of CFRPs on the Compressive Behavior of Confined Test Pieces and on the Flexural Behavior of Short Concrete Beams. Appl. Sci. 2021, 11, 491. https:// doi.org/10.3390/app11020491

Received: 21 December 2020

Accepted: 3 January 2021

Published: 6 January 2021

Publisher's Note: MDPI stays neutral with regard to jurisdictional clai$\mathrm{ms}$ in published maps and institutional affiliations.

Copyright: () 2021 by the authors. Licensee MDPI, Basel, Switzerland. This article is an open access article distributed under the terms and conditions of the Creative Commons Attribution (CC BY) license (https:// creativecommons.org/licenses/by/ $4.0 /)$.

\begin{abstract}
In this study, we compare the behavior of confined compression-tested concrete test pieces and short concrete beams subjected to three-point flexural strength testing when they are reinforced with high-modulus, high-strength carbon fibers reinforced polymers (CFRP). The fabrics used have roughly the same mechanical capacity but very different rigidities. As such, the results make it possible to obtain the influence of the rigidity of the CFRP on the structural behavior of the elements tested. The results obtained show that the type of fabric used does not cause significant differences in the values of tension of rupture and the form of rupture of the test pieces subjected to compression and flexural strength testing, which suggests that the variable which determines the mechanical response of the elements which have been reinforced and subjected to these kinds of demands is the mechanical capacity of the reinforcement, not its rigidity.
\end{abstract}

Keywords: concrete; reinforcements; CFRP; Young's modulus

\section{Introduction}

The rehabilitation of reinforced concrete structures (RCS) is an activity that is on the rise worldwide. It is often necessary to increase the resilience of RCS owing to changes in use which imply greater loads, structural interventions in order to install new openings, or pathological problems. Demolition and reconstruction of the structure is a very costly operation which requires a long period of time [1].

The use of composite materials made of fiber-reinforced polymers (FRP) started at the end of the Second World War in applications such as aviation, and at the end of the 1980s, their use reached the construction and infrastructures sector [2]. The first research project to investigate the option of using materials composed of FRP to reinforce concrete structures dates back to the year 1978 in Germany [3]. However, the first practical applications took place in Switzerland, in order to increase the bearing capacity on bending of reinforced concrete bridges $[4,5]$.

The use of this technique has become widespread in recent years, both at an experimental level and in practical applications [6]. The main advantages which justify the prevalence of this kind of system include their durability, extremely high strength-weight ratio, low maintenance costs, and the ease and speed with which the work can be implemented, barely interfering with the structure's operation [7].

FRP containing carbon fibers (CFRP) are, in practice, the most commonly used composites and those which generate the greatest interest among researchers. Depending on the manufacturing process, it is possible to obtain carbon fibers with different mechanical 
properties. Specifically, the application of temperature increases during the final heat treatment-graphitization-produces significant increases in the material's modulus of elasticity whilst slightly reducing its tensile strength [8-10]. As such, it is possible to find high-strength (HR) carbon fibers on the market which have longitudinal modulus of elasticity values of 215-235 GPa and breaking strains of 3500-4800 MPa, as well as highmodulus-of-elasticity (HM) fibers which have longitudinal modulus of elasticity values of 350-500 GPa and breaking strains of 2500-3100 MPa [11].

The reinforcement of concrete beams using FRP is an established technique both in terms of practical implementations and at a research level. The increase in flexural strength was assessed, obtaining results of as much as $160 \%$, when the FRP was attached to the exterior of the area under tensile stress of these beams [12-14]. Excellent results were also obtained when the beams underwent shear [15-20] and pure torsional reinforcement [21]. The experiments carried out have served to develop a significant body of rules and regulations [22-26].

Another relatively unknown aspect is the behavior of this type of reinforcement in short beams; it is not possible to apply the general theory of beams to their analysis since all regions of the beam are in areas of discontinuity, in which it is not possible to assume that planar sections remain planar after deformation (D regions). This type of region can be examined using a hypothetical truss with articulated joints composed of struts and tensioners connected to the nodes $[27,28]$.

There are various procedures for increasing the strength of reinforced concrete pillars. Using jacketing, generally made of steel or concrete, the strong section is increased and, consequently, so is the load capacity [29-32]. The confinement of the concrete results in increased mechanical capacity and ductility of the existing concrete.

The confinement of concrete can be achieved in various ways. The incorporation of external metallic tubes and filling the existing space between the pillar and the tube with high-modulus-of-elasticity concretes has been used for decades, and the technique continues to generate researchers' interest up to the present day [33-36].

The initial applications of the FRP-confinement technique in reinforced concrete (RC) columns took place in Japan in the 1980s [37,38]. However, the use of FRPs in Japan suddenly increased in 1995 following the earthquake in Hyogoken Nanbu [39]. Despite being a more recent technique, there are plenty of practical applications and laboratory projects which make it possible to endorse the suitability of the procedure. Research has been carried out into the performance of medium-strength concretes confined using carbon, glass, and aramid fiber fabrics and subjected to the central application of compressive force $[7,40-49]$ or to eccentric loads $[50,51]$. The performance of confined high-strength concretes has also been evaluated [52,53]. All cases have shown that the lower the strength of the confined concrete, the greater the benefits of confinement are [54-56]; that loading cycles reduce the rigidity of the element [57-59]; that large implementation defects only entail small decreases in strength [60]; and that the preload value of the element to be reinforced plays a very important role in the behavior of the reinforced element [61].

\section{Model of Confined Concrete and Fiber Deformation Capacity Limit}

\subsection{Model of Confined Concrete}

The first analytical expression linking the strength of confined concrete with the confinement pressure was proposed based on experimental results [62]. Since then, new models have been developed to predict the behavior of concretes confined using steel elements $[63,64]$. These models are not valid for concrete elements confined with FRP due to the fact that steel has a significant plastic deformation capacity prior to fracturing; however, in the case of FRP, the behavior is elastic and linear $[65,66]$.

In practice, the most commonly used models for predicting the breaking strain of concrete elements confined with CFRP are the ACI model [23] and the FIB model [22]. Table 1 shows both models for elements with a circular cross section, where $f_{c c}$ is the strength of the confined concrete, $f_{c}$ is the strength of the non-confined concrete, $f_{l}$ is the 
effective stress of the confinement, $\varphi_{f}$ is a reduction coefficient which the ACI takes as 0.95 , $E_{f}$ is the modulus of elasticity of the fiber, $n$ is the number of layers, $t_{f}$ is the thickness of the fabric, $D$ is the diameter of the confined element, and $\varepsilon_{f u}$ is the ultimate strain of the fabric. It is necessary to reduce the fabric's ultimate strain value obtained in uniaxial tension testing for the calculations; this is because the performance of the fabric in a confined material differs from the ideal tensile strength testing situation due to the state of triaxial stress it is in, the curved shape of the jacket, the possible damage during execution, and the stress concentration produced by irregularities in the concrete. The ACI proposes a value of 0.55 ; the FIB does not propose any specific value and points out that it is necessary to carry out prior testing in order to determine this value.

Table 1. ACI and FIB models for confined concrete.

\begin{tabular}{cc}
\hline ACI $440-17$ & FIB \\
\hline$f_{c c}=f_{c}+\varphi_{f} \cdot 3.3 \cdot f_{l}$ & $f_{c c}=f_{c}\left(2.254 \sqrt{1+7.94 \frac{f_{l}}{f_{c}}}-2 \frac{f_{l}}{f_{c}}-1.254\right)$ \\
$\frac{2 E_{f} \cdot n \cdot t_{f} \cdot 0.55 \cdot \varepsilon_{f u}}{D}$ & $f_{l}=\frac{2 E_{f} \cdot n \cdot t_{f} \cdot k \cdot \varepsilon_{f u}}{D}$ \\
\hline
\end{tabular}

Both models involve the same variables: the geometrical and mechanical characteristics of the original element and of the reinforcement fiber. However, examination of both expressions reveals that whilst in the ACI model the increase in strength does not depend on the initial strength of the non-confined concrete, in the FIB model the increase in strength does depend on the strength of the non-confined concrete.

\subsection{Fiber Deformation Capacity Limit}

However, there are issues where there is still insufficient consensus, such as the maximum strain capacity that FRP can bear before fracturing. ACI 440 [23] limits the strain capacity of the fiber from its ultimate strain $\varepsilon_{f u}$ to its design strain $\varepsilon_{f d}$ by means of Equation (1), in order to prevent faults due to tearing or the detachment of the concrete, depending on the compressive strength of the concrete $f_{c}$, the number of layers of fiber $n$, its modulus of elasticity $E_{f}$, and its thickness. This expression is based on research by Teng et al. $[67,68]$, who analyzed a large number of existing tests.

$$
\varepsilon_{f d}=\sqrt{\frac{f_{c}}{n \cdot E_{f} \cdot t_{f}}} \leq 0.9 \varepsilon_{f u}
$$

In this study, we compare the behavior of confined compression-tested concrete test pieces and short concrete beams subjected to three-point flexural strength testing when they are reinforced with high-modulus, high-strength CFRP. The results make it possible to obtain the influence of the rigidity of the CFRP on the structural behavior of the elements tested.

\section{Materials and Methods}

\subsection{Confined Test Pieces}

Nine cylindrical concrete test pieces were produced, measuring $150 \mathrm{~mm}$ in diameter and $300 \mathrm{~mm}$ in height in accordance with regulation NCh 170 [69] (Figure 1).

The concrete dosage we used can be seen in Table 2 .

The test pieces were removed from their molds after $24 \mathrm{~h}$ and were placed in a humidity chamber, immersed in limewater for 28 days, after which the faces of the test piece were flattened and given a parallel structure using a Triple Hi-Kenma TSURU-TSURU concrete specimen end grinding machine, in accordance with NCh 1172 [70]. 


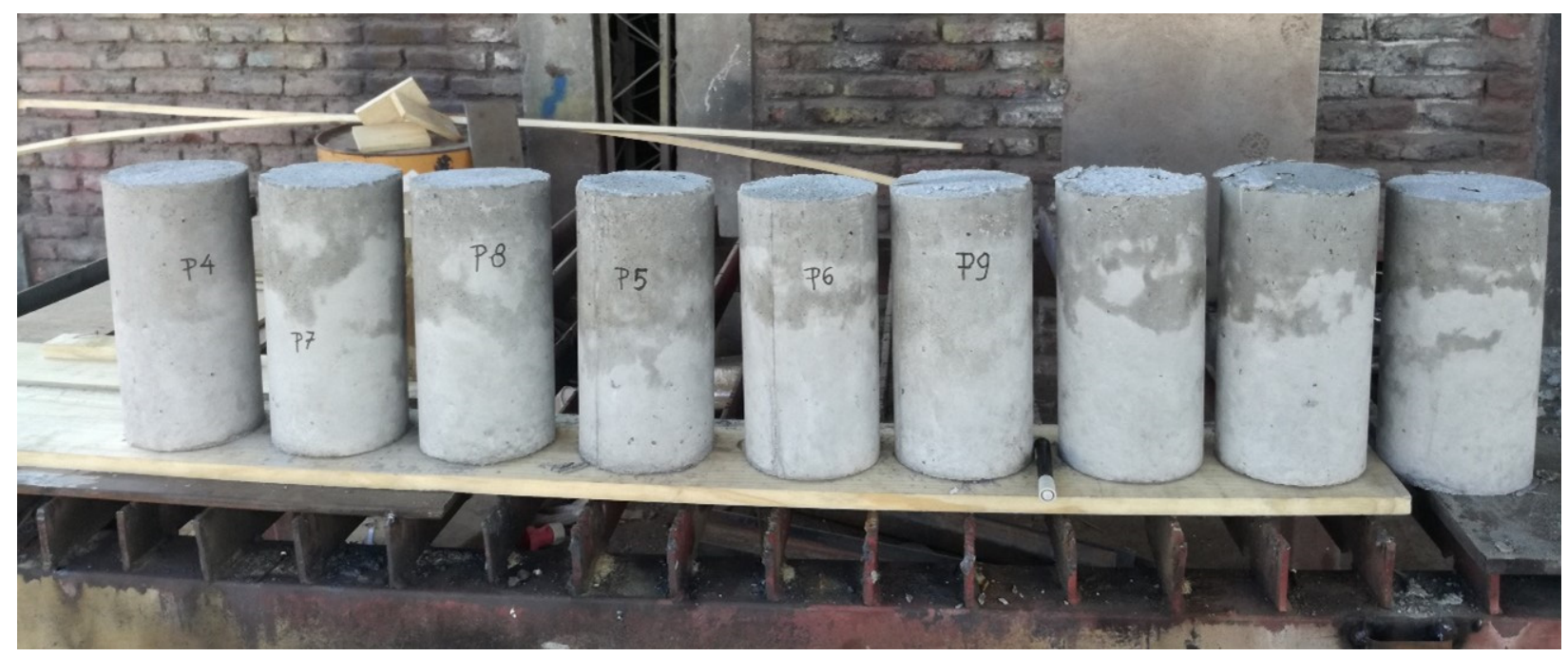

Figure 1. Image of the nine test pieces produced for compression testing.

Table 2. Dosage of the concrete used.

\begin{tabular}{cc}
\hline Material & Dosage (kg) \\
\hline Cement & 346 \\
Gravel & 879 \\
Sand & 950 \\
Water & 123 \\
Plasticizer & 2.1 \\
\hline
\end{tabular}

The six remaining test pieces were reinforced by gluing the carbon fiber fabrics with epoxy resins. Both the carbon fiber fabrics and the epoxy resins were supplied by MAPEI. The gluing was carried out by applying a first layer of resin and gluing the fabric to the specimen, leaving an overlap of $150 \mathrm{~mm}$ (indicated by the company) to avoid detachment of the fabric when it entered the load. Subsequently, a roller was applied to the outer surface to eliminate air pockets and imperfections in the execution. The tissue was cut with lesser height than the specimen to prevent it from being loaded in the compression direction, which would cause it to buckle. Two kinds of unidirectional carbon fiber fabric were used: a carbon fiber fabric with a normal modulus of elasticity and high strength (HR) with the trade name C-UNI-AX, and a fabric with a high modulus of elasticity (HM) with the trade name C-UNI-AX-HM. The geometrical and mechanical characteristics of both fabrics are set out in Table 3. Here, $e$ is the thickness equivalent of the fabric, $\sigma_{r}$ is the ultimate tensile strength, $E$ is the longitudinal modulus of elasticity, $\varepsilon_{f u}$ is the ultimate tensile strain, $F_{r}$ is the mechanical capacity of the fiber under tensile stress per unit of length, and $K_{r}$ is the rigidity of the fiber under tensile stress per unit of length. All the pieces were subsequently compression tested until breaking point. The tests were performed in the Materials Laboratory of the Central University of Santiago de Chile (LEMUC), using a Druck-und Biegeprüfmaschine press at a speed of $1 \mathrm{MPa} / \mathrm{s}$ and following regulation NCh 1037 [71].

Table 3. Geometrical and mechanical characteristics of the fabrics used.

\begin{tabular}{ccccccc}
\hline & $\begin{array}{c}\boldsymbol{e} \\
(\mathbf{m m})\end{array}$ & $\begin{array}{c}\sigma_{r} \\
\mathbf{( M P a )}\end{array}$ & $\begin{array}{c}\boldsymbol{E} \\
\mathbf{( G P a )}\end{array}$ & $\begin{array}{c}\varepsilon_{f u} \\
\mathbf{( \% )}\end{array}$ & $\begin{array}{c}\boldsymbol{F}_{\boldsymbol{r}} \\
\mathbf{( N / m m )}\end{array}$ & $\boldsymbol{K}_{\boldsymbol{r}} \mathbf{( k N / \mathbf { m m } )}$ \\
\hline C-UNI-AX (HR) & 0.166 & 4830 & 230 & 2.1 & 801.8 & 38.2 \\
C-UNI-AX-(HM) & 0.165 & 4410 & 390 & 1.1 & 727.6 & 64.3 \\
\hline
\end{tabular}


The breaking strain and modulus of elasticity values of both fabrics made it possible to classify them as being of high strength and high modulus [11].

The choice of these types of fiber made it possible to compare the influence of the rigidity of the fabric on the compressive behavior of the confined test pieces, due to the fact that both fabrics provide practically the same mechanical capacity $(801.8 \mathrm{~N} / \mathrm{mm}$ compared to $727.6 \mathrm{~N} / \mathrm{mm})$ but have very different rigidities $(38.2 \mathrm{kN} / \mathrm{mm}$ compared to $64.3 \mathrm{kN} / \mathrm{m})$.

\subsection{Short Beams}

In order to test the behavior of the HR and HM fibers when they are used to reinforce short concrete beams, eight beams measuring $530 \mathrm{~mm}$ in length and with a cross section of $100 \mathrm{~mm}$ in width and $150 \mathrm{~mm}$ in height were produced. The dosage of the concrete used was the same as that used for the confined test pieces and can be seen in Table 2, with an average breaking strain of $46.2 \mathrm{MPa}$. The beams were reinforced with a symmetrical longitudinal frame composed of two rods above and two rods below, each with a diameter of $6 \mathrm{~mm}$ (2Ф6). Six-millimeter brackets were placed every $170 \mathrm{~mm}$ (EФ6@170 mm) which, due to their separation, did not contribute to the shear strength of the beam; their only mission was to secure the position of the longitudinal frame. The steel used for the frame was of A 360/420H quality; in other words, it has an elastic limit of $360 \mathrm{MPa}$ and breaking strain of $420 \mathrm{MPa}$. Three beams were reinforced by attaching HR carbon fiber fabric to the exterior using epoxy resin, a further three were reinforced using HM carbon fiber fabric, and the remaining three were left unreinforced to form a benchmark. The characteristics of the fibers used are set out in Table 3. Data could not be recorded for one of the beams reinforced with HR fibers, which is why they are not provided. The fabrics completely covered the beams.

The beams were mounted on two supports and were subjected to flexural strength testing, using a central point load until fracturing occurred. A $100 \mathrm{kN}$ hydraulic loading frame machine manufactured by "Daiman" was used. The vertical displacements were measured at the midpoint of the beam using an optical transducer sensor with $200 \mathrm{~mm}$ stroke, series 220001-01, manufactured by "Control de Procesos y Sistemas Ltd.a." The tests were carried out using a displacement control speed of $1 \mathrm{~mm} / \mathrm{min}$. Figure 2 shows a diagram of the beams tested (Figure 2a,b) and the experiment layout (Figure 2c).

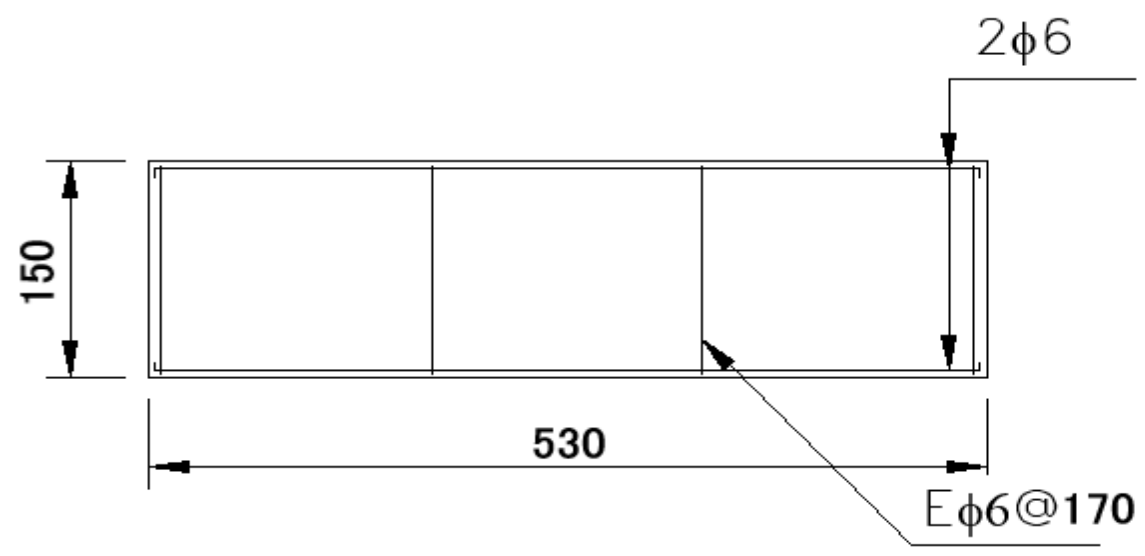

(a) Front view of the beam

Figure 2. Cont. 


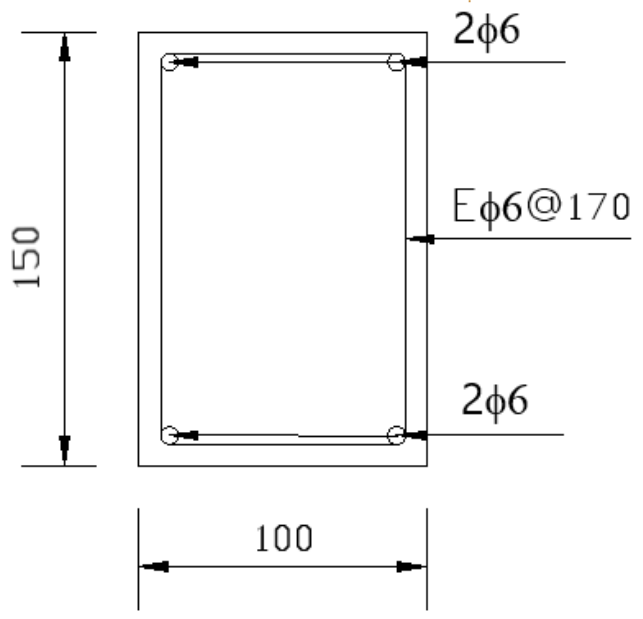

(b) Section of the beam

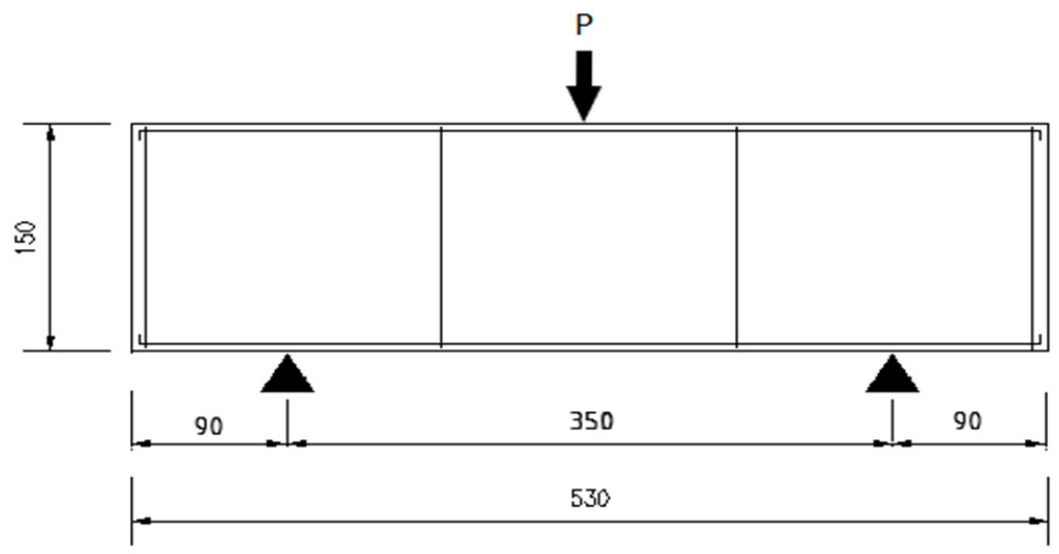

(c) Design of the experiment

Figure 2. Diagram of the beams tested and the experiment layout.

\section{Discussion}

\subsection{Confined Test Pieces}

Figure 3 shows images of the test pieces once testing was complete. It can be seen that in the six cases the fault type was very similar and occurred due to the fracturing of the fibers under tensile strength. The fracture was preceded by a loud cracking sound before the fiber snapped. The only difference that could be observed was that whilst the fault in the test pieces reinforced with HM (Figure 3b) fibers occurred in three test pieces due to the fracturing of fibers throughout the length of the test piece, in the test pieces reinforced with fibers of a lower modulus (Figure 3a), this only happened in one of them, whilst in the other two test pieces, the fracturing of the fibers only occurred in the central third.

Table 4 shows the breaking strain values, $\sigma_{r}$, obtained in the compression tests, as well as the average values $\bar{x}_{\sigma \mathrm{r}}$, the typical deviation $s_{\sigma r}$, and the percentage strength increase $\Delta_{\sigma r}$ experienced by the reinforced test pieces compared to the benchmark specimens. 

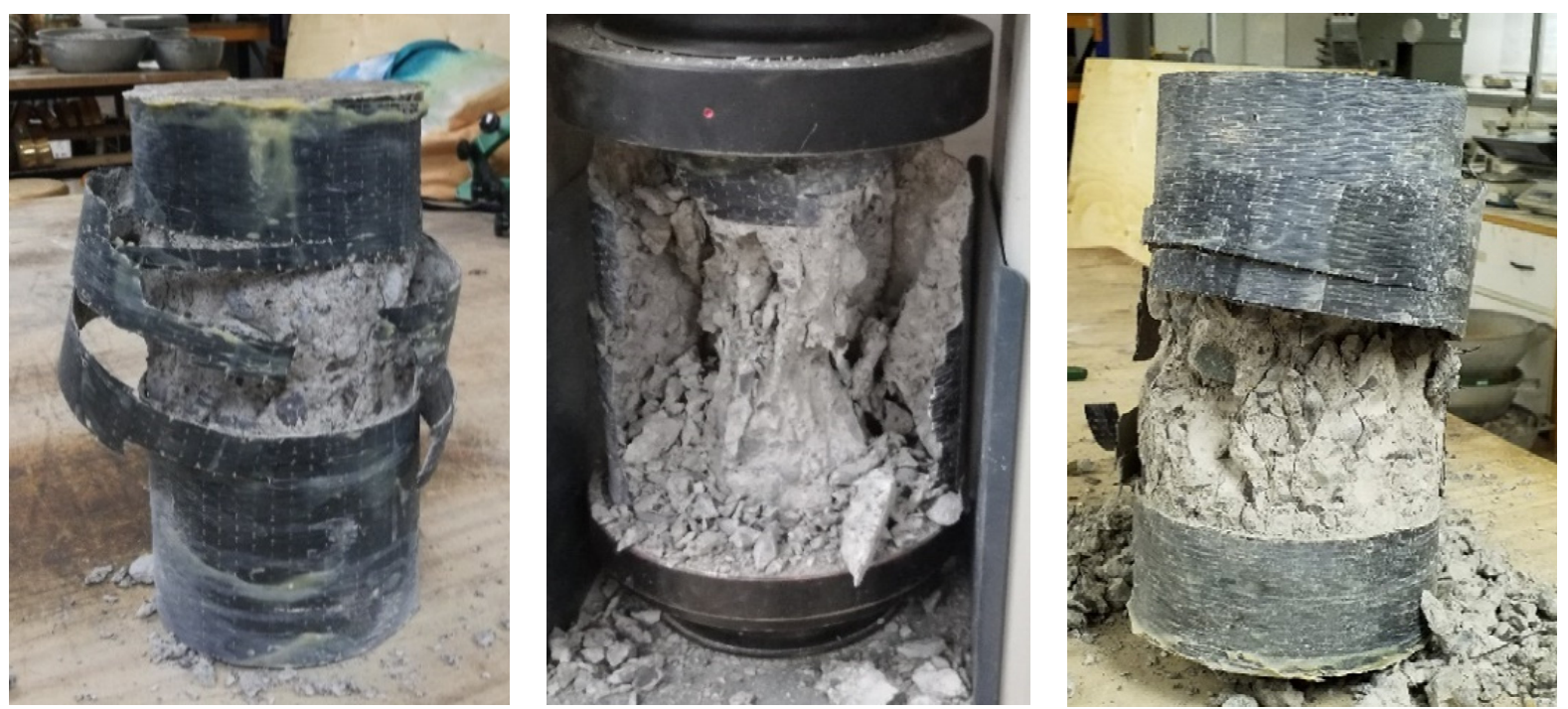

(a) Test pieces reinforced with HR fibers (N1, N2, N3).
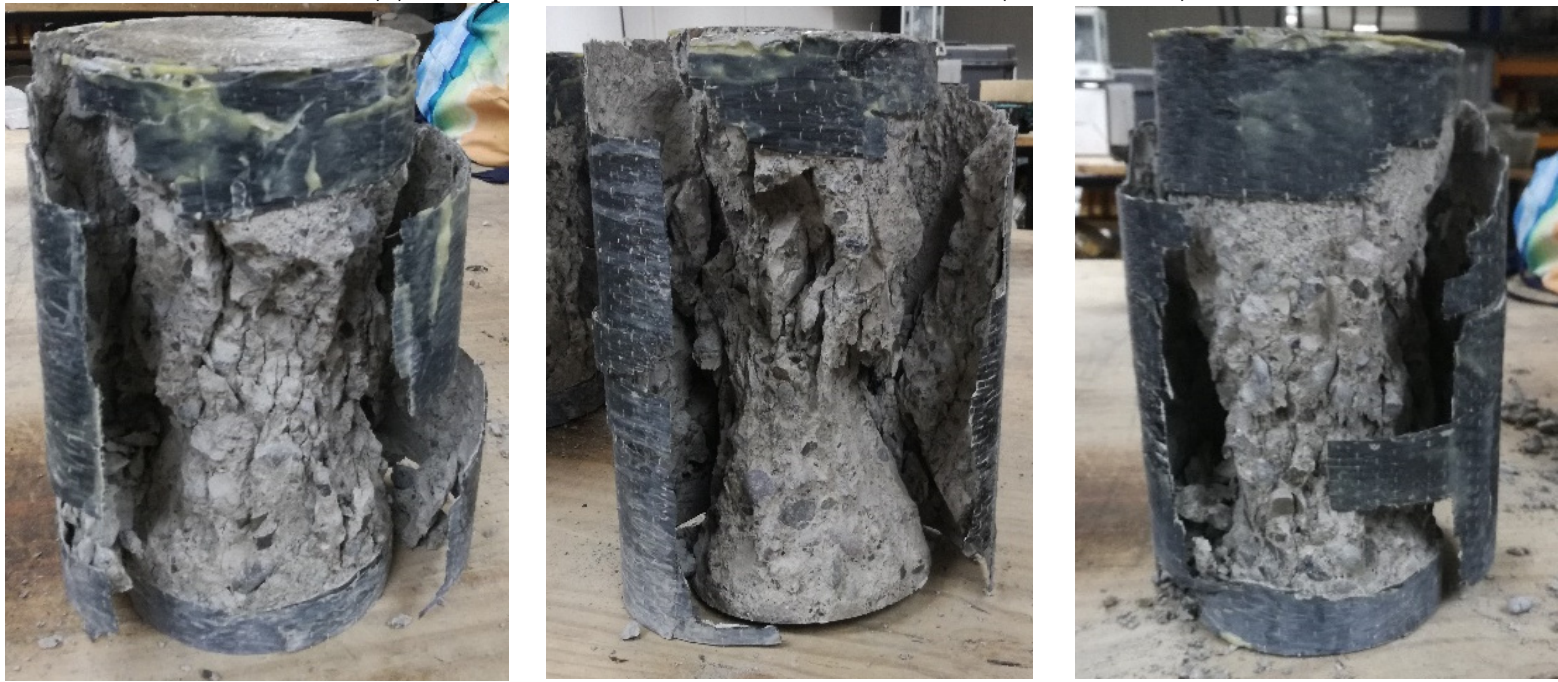

(b) Test pieces reinforced with HM fibers (H1, H2, H3).

Figure 3. Images of fracturing in the compression-tested pieces.

Table 4. Results of compression testing: average values, typical deviation, and strength increase.

\begin{tabular}{|c|c|c|c|c|c|}
\hline Test Piece & Confinement & $\sigma_{r}(\mathrm{MPa})$ & $\bar{x}_{\sigma \mathrm{r}}(\mathrm{MPa})$ & $s_{\sigma r}(\mathrm{MPa})$ & $\Delta_{\sigma r}(\%)$ \\
\hline $\mathrm{C} 1$ & & 44.6 & & & \\
\hline $\mathrm{C} 2$ & Non-confined & 45.1 & 46.5 & 2.93 & - \\
\hline $\mathrm{C} 3$ & & 49.9 & & & \\
\hline N1 & & 74.2 & & & \\
\hline N2 & $\mathrm{HR}$ & 67.6 & 68.9 & 4.74 & 1.48 \\
\hline N3 & & 65.0 & & & \\
\hline $\mathrm{H} 1$ & & 70.0 & & & \\
\hline $\mathrm{H} 2$ & HM & 71.4 & 71.5 & 1.55 & 1.54 \\
\hline H3 & & 73.1 & & & \\
\hline
\end{tabular}

The results in Table 4 show that both fabrics provide an effective way of reinforcing concrete elements subjected to compression. In both cases, increases in strength of around $50 \%$ were obtained compared to the strength of the original element. This value is the maximum recommended by documents which regulate the use of this type of reinforcement system due to their vulnerability when exposed to fire or vandalism [23]. Both types of 
reinforcement delivered practically the same breaking load, despite the huge difference in the rigidity values. This seems to indicate that the decisive factor in the breaking load of the reinforced element is the mechanical capacity of the fiber under tensile strength, irrespective of its rigidity, always within the limits of the elements tested.

These data were analyzed using an ANOVA technique. This can help to globally decompose the observed error across all the data (nine samples) into the variance explained by the factor (here formed by three levels: non-confined, HR. and HM) and the variance not explained by the factor. In this way, compared to the separate measurements of mean and standard deviation for each level of the factor, the statistical significance is treated globally (because the null model assumes normally distributed, homoscedastic errors with the same variance for every level of the factor) and therefore turns out to be multiplied by three. Considered together, we can safely reject the null hypothesis of equal averages in the three compression tests performed (ANOVA $p$-value: 0.000174).

Paired means were also compared via the adjusted ANOVA model. Here, significant differences were found when comparing non-confined and HM treatments (Tukey contrast $p$-value: 0.00235 ) and when comparing non-confined and HR treatments (Tukey contrast $p$-value: 0.00431). However, there were no significant differences between the HM and HR treatments (Tukey contrast $p$-value: 0.6366). Therefore, it can be stated that confinement of the material significantly increases compression resistance, but there were no differences in strength between both types of analyzed confinement.

Table 5 shows the experimental and analytical values achieved by the reinforced test pieces when using the ACI and FIB models. With the FIB model, the value 0.55 was used as the reduction factor of the ultimate strain of the carbon fiber. This value is the same as that used for the ACI model, so as to be able to compare the results obtained by both procedures. The values that should have been taken for the coefficient $K$ which reduces the ultimate strain of the fiber have also been indicated so that the values provided for the ACI and FIB models coincide with the experimental values.

Table 5. Comparison between the experimental and analytical values for reinforced test pieces.

\begin{tabular}{cccccc}
\hline & $\begin{array}{c}\text { Experimental } \\
(\mathbf{M P a})\end{array}$ & $\begin{array}{c}\text { ACI } \\
\mathbf{( M P a )}\end{array}$ & $\begin{array}{c}\boldsymbol{K} \\
(\mathbf{A C I})\end{array}$ & $\begin{array}{c}\text { FIB } \\
\mathbf{( M P a})\end{array}$ & $\begin{array}{c}\boldsymbol{K} \\
\mathbf{( F I B )}\end{array}$ \\
\hline $\mathrm{HR}$ & 68.9 & 64.8 & 0.67 & 78.4 & 0.35 \\
$\mathrm{HM}$ & 71.5 & 62.6 & 0.85 & 75.3 & 0.47 \\
\hline
\end{tabular}

It can be observed that the ACI model predicted the experimental results obtained very well and that the values obtained by applying the formulas in this document remain somewhat on the conservative side. For the test pieces reinforced with HR, the value provided by the ACI model was $94 \%$ of the experimental value, whilst for the HM test pieces, it was $87 \%$. The FIB model values were higher than those predicted by the ACI model and remained on the uncertain side when a reduction of 0.55 was adopted for the ultimate strain of the fiber. For test pieces reinforced with HR, the FIB model predicted a breaking strain that was $14 \%$ higher than the real one, whilst for HM fiber it only deviated by $5 \%$ above the experimental value.

A large number of tests have been performed in order to determine the breaking strain values of CFRP fabrics when they confine concrete elements. Xiau and $\mathrm{Wu}$ (2000) [72] indicated values of 0.5-0.8, Lam and Teng (2003) [73] reported values of 0.58 and 0.91 , Harries and Carey (2003) [74] reported a value of 0.58, and Yang et al. (2001) [75] reported a value 0.66 . In this study, values of 0.35 and 0.47 were obtained for the FIB model and 0.67 and 0.85 for the ACI model, for HR and HM CFRP fabrics, respectively.

\subsection{Short Beams}

Figure 4 shows the load-displacement graph for the eight beams for which results were recorded. 


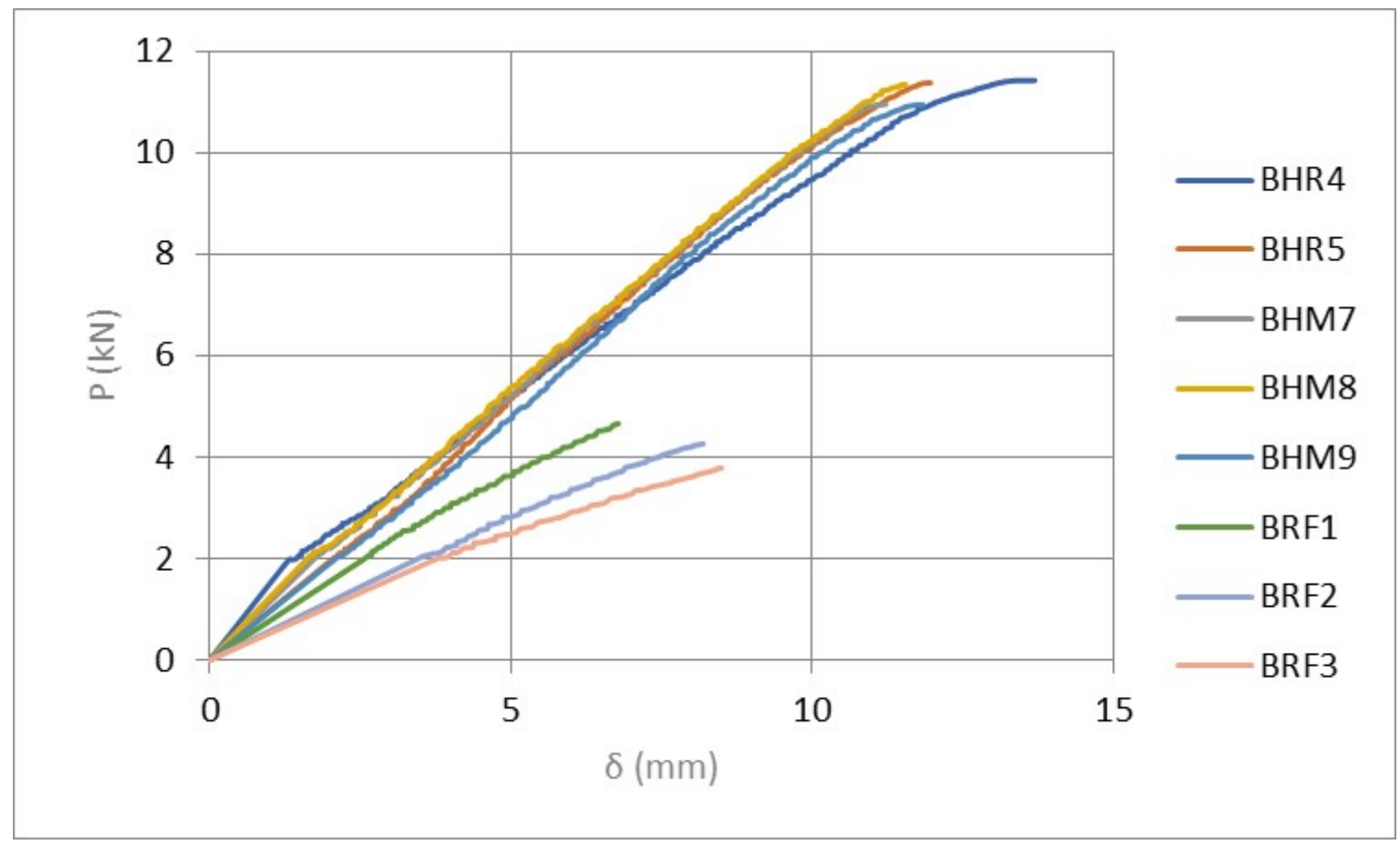

Figure 4. Load-displacement graph for the beams tested.

Table 6 shows the most significant results obtained from the graph in Figure 4: the maximum load reached in the test, $P_{\max }$; the displacement under this maximum load, $\delta_{\max }$; the rigidity of the beam, $K$, obtained in the interval $0.15 P_{\max }-0.35 P_{\max }$, where the behavior is linear; and the energy absorbed in the test, $G_{m a x}$, calculated as the area enclosed by the graph. The average values of the previous figures $(\bar{x})$ are also provided.

Table 6. Results obtained in the flexural strength tests.

\begin{tabular}{|c|c|c|c|c|c|c|c|c|}
\hline Beam & $\begin{array}{l}P_{\max } \\
(\mathbf{k N})\end{array}$ & $\begin{array}{l}- \\
\left(\bar{x}_{P}\right) \\
(\mathbf{k N})\end{array}$ & $\begin{array}{l}\delta_{\max } \\
(\mathrm{mm})\end{array}$ & $\begin{array}{l}\left(\bar{x}_{\delta}\right) \\
(\mathrm{mm})\end{array}$ & $\begin{array}{c}K \\
(\mathrm{kN} / \mathrm{mm})\end{array}$ & $\begin{array}{c}\left(\bar{x}_{\mathrm{k}}\right) \\
(\mathrm{kN} / \mathrm{mm})\end{array}$ & $\begin{array}{c}G_{\max } \\
(\mathrm{kN} \cdot \mathbf{m m})\end{array}$ & $\begin{array}{c}\left(\bar{x}_{\mathrm{G}}\right) \\
(\mathbf{k N} \cdot \mathbf{m m})\end{array}$ \\
\hline BRF1 & 46.6 & \multirow{3}{*}{46.0} & 6.8 & \multirow{3}{*}{7.8} & 0.77 & \multirow{3}{*}{0.62} & 160.7 & \multirow{3}{*}{180.9} \\
\hline BRF2 & 53.4 & & 8.2 & & 0.57 & & 218.9 & \\
\hline BRF3 & 37.9 & & 8.5 & & 0.52 & & 163.0 & \\
\hline BHR4 & 112.8 & \multirow{2}{*}{113.3} & 12.8 & \multirow{2}{*}{12.4} & 1.1 & \multirow{2}{*}{1.0} & 723.8 & \multirow{2}{*}{704.8} \\
\hline BHR5 & 113.8 & & 12.0 & & 1.0 & & 685.7 & \\
\hline BHM7 & 109.6 & \multirow{3}{*}{110.8} & 11.3 & \multirow{3}{*}{11.3} & 1.0 & \multirow{3}{*}{1.0} & 621.3 & \multirow{3}{*}{629.8} \\
\hline BHM8 & 113.5 & & 10.9 & & 1.0 & & 620.4 & \\
\hline BHM9 & 109.4 & & 11.8 & & 1.0 & & 647.6 & \\
\hline
\end{tabular}

The results in Table 6 and Figure 4 demonstrate that the behavior of the beams tested was very fragile in all cases. The reinforcement procedure is thus seen to be highly effective. The reinforced beams achieved highly significant increases in the values for breaking strain, ultimate displacement, rigidity, and energy absorbed in the tests. Furthermore, there were no differences between the behaviors of the beams reinforced using the two types of fiber. The five curves obtained for these beams are virtually overlapping; however, significant differences can be observed between the three diagrams obtained for the unreinforced beams. 
The flexural strength tests were analyzed using ANOVA tests. This methodology treats jointly the set of eight samples that are had in this case. Two ANOVA tests were conducted: one for the breaking load and another for the maximum displacement.

For the breaking load experiments, significant differences were found between the three levels of the factor. The resulting ANOVA $p$-value $\left(p=3.21 \times 10^{5}\right)$ led us to reject the null hypothesis of equal averages. Table 7 summarizes the Tukey contrasts of pairwise mean comparisons.

Table 7. Results of the analysis ANOVA for the breaking load.

\begin{tabular}{cc}
\hline Compared Levels & $p$-Value \\
\hline BHM-BHR & 0.854 \\
BHM-BRF & $6.98 \times 10^{-5 * * *}$ \\
BHR-BRF & $5.79 \times 10^{-5 * * *}$ \\
\hline
\end{tabular}

*** The $p$-value is $<$ than $10 \times 10^{-3}$.

Therefore, BHM-BRF and BHR-BRF are significantly different, but the hypothesis that $\mathrm{BHM}$ and BHR averages are equal cannot be rejected.

For the maximum displacement experiments, significant differences were also found between the three levels of the factor. The resulting ANOVA $p$-value $(p=0.00142)$ led us to reject the null hypothesis of equal averages (here with a lesser degree of confidence, because the $p$-value is larger but lies within the significant range). Table 8 summarizes the Tukey contrasts of pairwise mean comparisons.

Table 8. Results of the analysis ANOVA for the displacement.

\begin{tabular}{cc}
\hline Compared Levels & $p$-Value \\
\hline BHM-BHR & 0.27495 \\
BHM-BRF & $0.00513^{* *}$ \\
BHR-BRF & $0.00155^{* *}$ \\
\hline
\end{tabular}

** The $p$-value is $<10 \times 10^{-2}$ and $>10 \times 10^{-3}$.

Therefore, consistent with what was found for the breaking load experiments, the BHM-BRF and BHR-BRF treatments are significantly different, while the hypothesis that $\mathrm{BHM}$ and BHR averages are equal cannot be rejected.

All of the beams displayed a brittle fracture, with a crack that is typical of a shear fracture (Figure 5). There were no differences between the types of fracture in the beams reinforced with both types of fiber. A crack formed between the load application point and the edge of the support, which was more open in the lower area and gradually narrowed as it reached the load application point. In the central area of the beam, the crack took on a step-like shape, but on joining the two ends of the crack, a straight line was obtained which cut the steps roughly in half. In the beams which were not reinforced with fibers, the type of fracture was very similar, appearing as a crack which, as in the aforementioned case, spanned from the edge of the support to the load application point; however, in this case, the shape of the crack was not a straight line, but rather a curve, which is typical of shear cracking in unreinforced concrete elements. Cracking occurs when the principal tensile stress in the concrete exceeds the tensile strength of the concrete. Due to the non-existence of stirrups and fibers that can contribute to the resistance to shear stress, when the tensile strength of the concrete is reached, the crack becomes larger and the central zone slides downwards with respect to the zone that remains in the supports. In the beam BHM8, the pin effect of the tensile reinforcement could be verified. 


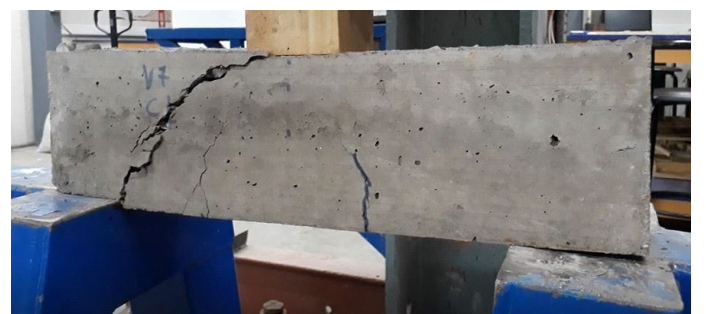

BRF1

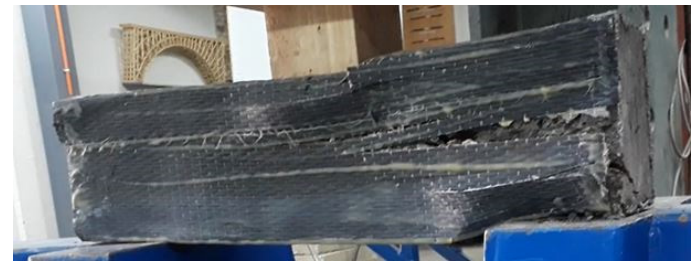

BHR4

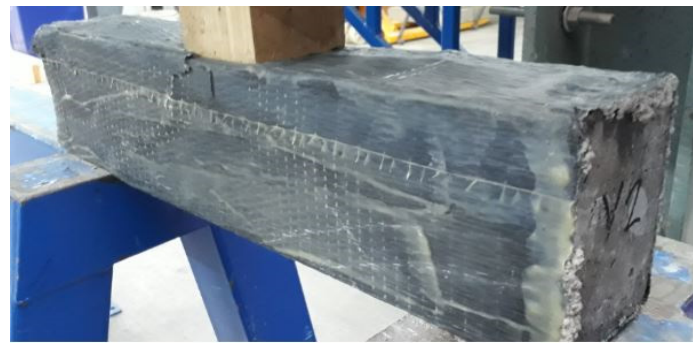

BHR5

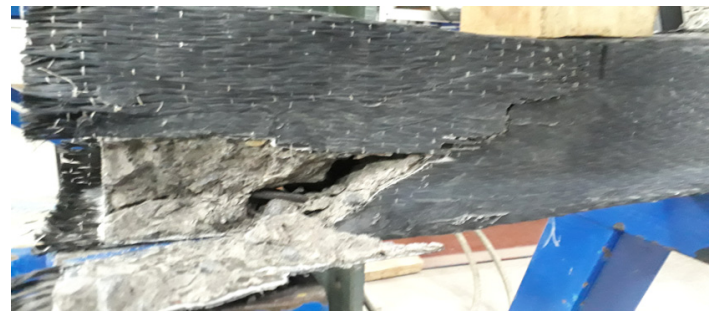

BHM8

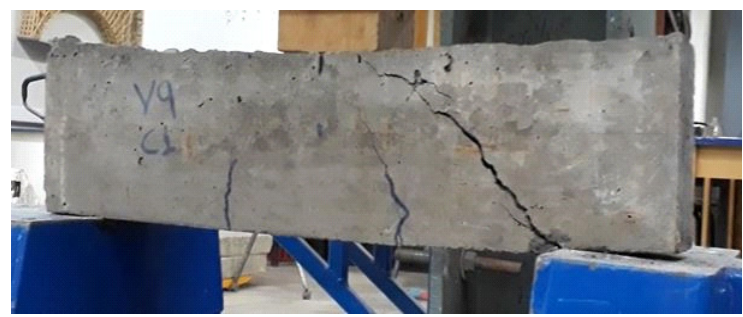

BRF3

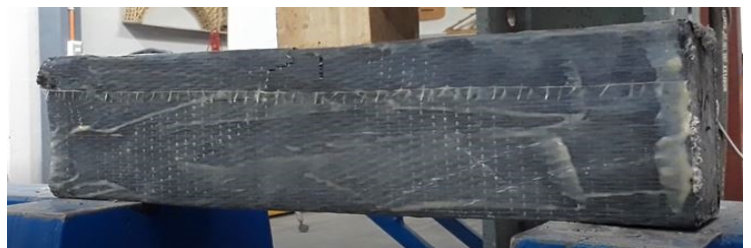

BHR5

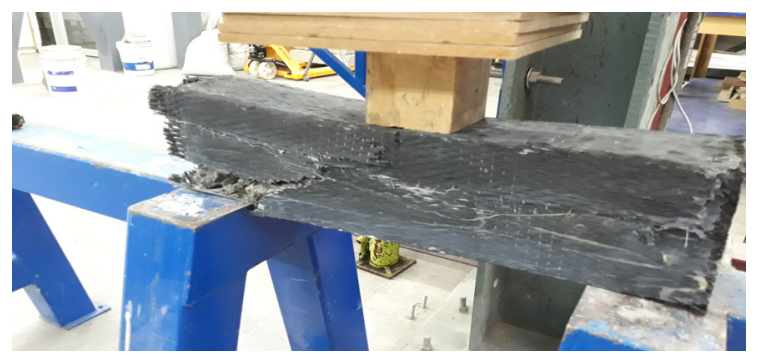

BHM7

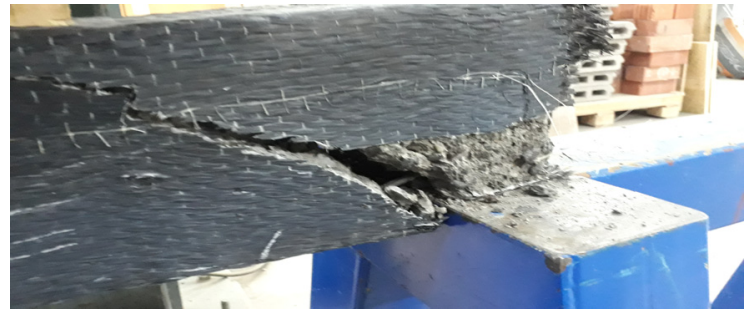

BHM9

Figure 5. Images of the beams after flexural strength testing.

Figure 6 shows the increases in the average values achieved by the reinforced beams compared to the benchmark beams.

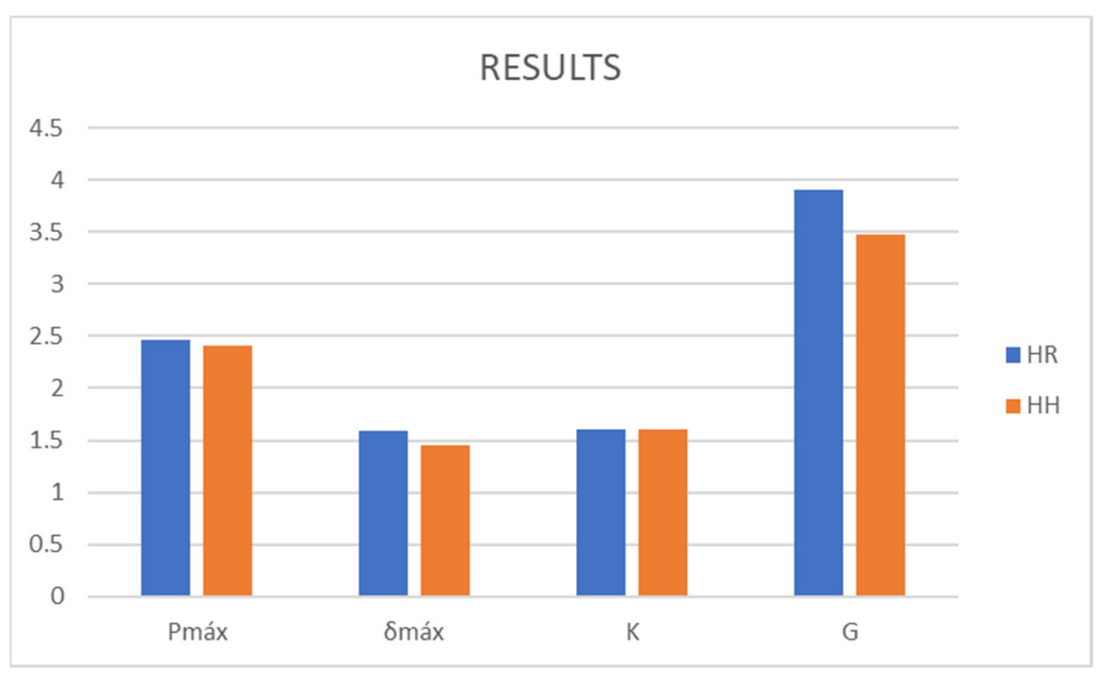

Figure 6. Increases in the average values of the properties of reinforced beams. 
The data in Figure 6 show once again that both types of reinforcement are highly effective because they brought about a highly significant improvement in the structural response of reinforced elements. Furthermore, the results obtained were very similar and, excluding the case of rigidity, the increases achieved using HR fibers were slightly higher than those achieved using HM fibers. A significant increase in the load capacity of the beams was observed when the beams were reinforced using either of the two procedures. Both with the HR fibers and with HM fibers, increases in load were achieved which more than doubled ( 2.5 and 2.4 times, respectively) the load for the benchmark beams. In the case of the energy absorbed during the test, the increases were even higher: 3.9 times higher with HR fibers and 3.5 times higher with HM fibers. The displacements of the reinforced beams also exhibited significant increases, recorded at 1.6 times higher (HR) and 1.5 times higher (HM). In the case of rigidity, the same results were obtained with both types of fabric, $50 \%$ more than those for the unreinforced beam.

The analysis of a beam such as that tested cannot be carried out using the Bernoulli beam model since all regions of the beam are in $\mathrm{D}$ regions and, as such, they do not fulfil the assumption of having flat sections both before and after the strain. The analysis must be performed using the rods and straps method [76,77]. In order to carry out the analysis, the model in Figure 7 was selected, which is composed of two inclined concrete rods and a steel (BRF beams) or mixed steel and concrete (BHR and BHM beams) strap.

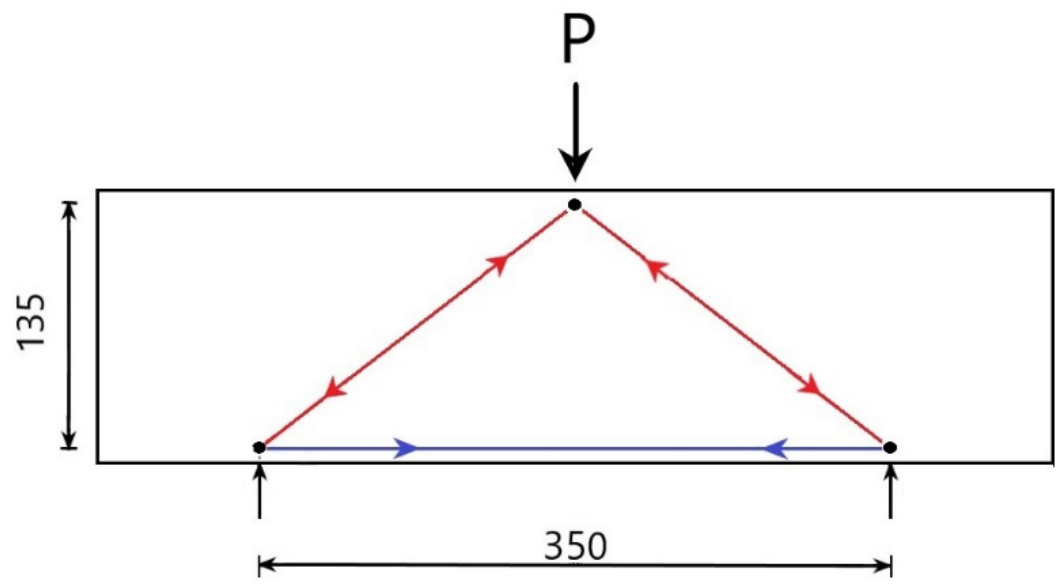

Figure 7. Rods and straps model used for the analysis.

Table 9 shows the results obtained from the analysis carried out.

Table 9. Results of analysis via the rods and straps method.

\begin{tabular}{ccccccc}
\hline Beam & $\boldsymbol{P}_{\boldsymbol{m a x}}(\mathbf{k N})$ & $\boldsymbol{U}_{\boldsymbol{f}}(\mathbf{k N})$ & $\boldsymbol{U}_{\boldsymbol{t h}}(\mathbf{k N})$ & $\boldsymbol{P}_{\boldsymbol{t h}}(\mathbf{k N})$ & $\boldsymbol{U}_{\boldsymbol{t h}}^{\prime}(\mathbf{k N})$ & $\boldsymbol{P}_{\boldsymbol{t h}}^{\prime}(\mathbf{k N})$ \\
\hline $\mathrm{BRF}$ & 46.0 & 0 & $23.8 / 35.6$ & $36.6 / 54.8$ & 29.9 & 46.0 \\
$\mathrm{BHR}$ & 114.0 & 160.4 & $184.2 / 196.0$ & $283.2 / 301.3$ & 190.3 & 292.6 \\
$\mathrm{BHM}$ & 110.8 & 145.6 & $169.4 / 181.2$ & $261.0 / 279.3$ & 175.5 & 270.0 \\
\hline
\end{tabular}

The second column shows the average value of the breaking load in the beams tested as obtained through experiments $\left(P_{\max }\right)$. The third column shows the mechanical capacity of the fabrics $\left(U_{f}\right)$. This was obtained by multiplying the force that the fabric is capable of developing per unit of length (Table 3 ) by the length of fabric being used as a strap, which was taken to be $200 \mathrm{~mm}$ for the underside of the beam $(100 \mathrm{~mm})$ and $50 \mathrm{~mm}$ for each side. The fourth column shows the mechanical capacity of the beams under tensile stress $\left(U_{t h}\right)$, obtained as the sum of the mechanical capacities of the frame and of the HR or HM fiber. For the mechanical capacity of the frame, the data associated with the working capacity in elastic state were used: $23.8 \mathrm{kN}$ or $35.6 \mathrm{kN}$ at fracture. In the rows related to 
the beams reinforced with fibers, the mechanical capacity values obtained are indicated as the sum of the capacity of the steel in elastic state plus the fiber and the sum of the capacity in elastic state plus the fiber. The fifth column sets out the theoretical maximum test load $\left(P_{t h}\right)$ obtained by using the mechanical capacities from the previous table. Once again, two values are provided, based on the mechanical capacity of the steel considered. The sixth column details the average mechanical capacities for each type of beam when the value of $29.9 \mathrm{kN}\left(U_{t h}^{\prime}\right)$ was used as the mechanical capacity of the steel. This value was calculated analytically using the rods and straps model and using the value obtained through experiments as the breaking load. The value of $29.9 \mathrm{kN}$ exceeds the mechanical capacity of steel in elastic state but does not reach the capacity upon fracture, which indicates that the steel has plastified when the beam fractures. The mechanical capacities of the reinforced beams under tensile stress were obtained using this value. The values contained in the last column refer to the theoretical maximum test load obtained when the mechanical value of the steel that was really deployed was used in the calculations $\left(P_{t h}^{\prime}\right)$. This value was obtained in the model using the real load obtained in the test.

It can be seen how both the values for $P_{t h}$, using the theoretical mechanical capacity of frames and fibers, and the values for $P^{\prime}{ }_{t h}$, using the mechanical capacity developed by the frame plus the theoretical mechanical capacities for the fibers, are very similar, since the load capacity for both types of fabric is also very similar. Furthermore, both values are much higher than the test loads, practically tripling them, which indicates that the performance capacity of these fabrics is very low in terms of heavy-duty performance.

The difference between the maximum experiment load values reached by the reinforced beams $\left(P_{\max } \mathrm{BH}\right)$ and by the unreinforced beams $\left(P_{\max } \mathrm{BR}\right)$ provides an estimate of the value of the test load withstood by the fiber fabrics $\left(P_{f}\right)$. Using the latter value, it is possible to obtain the force withstood by the fabrics $\left(U_{f}\right)$, the performance percentage of each $(A)$, and the strain reached $\left(\varepsilon_{f}\right)$, which can be compared with the maximum strain indicated by the $\mathrm{ACI}\left(\varepsilon_{f, A C I}\right)$ using Equation (1). It was observed that the strain reached by the fabrics is compatible with the strain reached by the frames in order to overcome the elastic state (Table 10).

Table 10. Analytical estimation of the strain reached by the fabrics, $\varepsilon_{f}$.

\begin{tabular}{ccccccc}
\hline & $\boldsymbol{P}_{\max }(\mathbf{k N})$ & $\boldsymbol{P}_{\boldsymbol{f}}(\mathbf{k N})$ & $\boldsymbol{U}_{\boldsymbol{f}}(\mathbf{k N})$ & $\boldsymbol{A}(\mathbf{\%})$ & $\boldsymbol{\varepsilon}_{f}(\mathbf{\%})$ & $\varepsilon_{f, A C I}(\mathbf{\%})$ \\
\hline $\mathrm{BR}$ & 46.0 & & & & & \\
$\mathrm{HR}$ & 114.0 & 68 & 44.2 & 28 & 0.59 & $3.5 \leq 1.9$ \\
$\mathrm{HM}$ & 110.8 & 64.8 & 44.1 & 29 & 0.32 & $2.7 \leq 1.0$ \\
\hline
\end{tabular}

The values obtained for fabric strain, $\varepsilon_{f}$, suggest a fabric performance of $28-29 \%$, significantly below the values reached in the case of confinement. These values are also much lower, by approximately two-thirds, than the design values indicated by the ACI $\varepsilon_{f, A C I}: 0.59 \%$ compared to $1.9 \%$ and $0.32 \%$ compared to $1.0 \%$.

\section{Conclusions}

Cylindrical concrete test pieces were compression tested until breaking point and short reinforced concrete beams were subjected to three-point flexural strength testing. The results were compared with those of identical test pieces confined with carbon fiber fabrics featuring two very different moduli of elasticity. Based on the results, the following conclusions may be reached:

- In confined elements, the type of fracture and breaking load were very similar for both types of reinforcement, despite the enormous difference in rigidity of the fabrics providing confinement. The fault occurred due to the fracturing of fibers under tensile stress. For the purposes of breaking load in confined elements, the rigidity of the casing plays a secondary role. 
- After analyzing the data regarding confined elements using an ANOVA technique, it can be stated that the confinement of the material significantly increases compression resistance, but there were no differences in strength between both types of analyzed confinement.

- In confined elements, the breaking loads obtained using the ACI and FIB models were very similar to those obtained through experiments on both types of test piece, and they remain on the conservative side when evaluated using the ACI model and on the uncertain side when the FIB model is used. Values of between 0.35 and 0.47 were obtained for the FIB model and between 0.67 and 0.85 for the ACI model as values for the reduction coefficient of the ultimate strain of the fiber, meaning that the analytical values match the experimental ones for HR and HM fabrics, respectively.

- The experimental breaking load for confined test pieces was very similar for both types of reinforcement and was significantly higher than the breaking load for the unreinforced test pieces. The theoretical breaking load in confined test pieces was also very similar for both types of reinforcement and almost triple the experimental breaking load.

- The experimental values obtained in short beams for the breaking load, maximum displacement, rigidity, and energy absorbed in the test were very similar and significantly exceeded those for the unreinforced beams.

- After analysis of the results regarding the breaking load and the maximum displacement of short beams using an ANOVA technique, we found significant BHM-BRF and BHR-BRF treatment differences, whereas we cannot reject the hypothesis that the BHM and BHR averages are equal.

- The theoretical breaking load for the beams reinforced using both procedures obtained using the rods and straps model was also very similar and almost triple the value of the theoretical breaking load. The values obtained for fabric strain, $\varepsilon_{\mathrm{f}}$, suggest a fabric performance of $28-29 \%$.

By way of general conclusion, it can be noted that the results obtained reveal a huge similarity between the behavior of the test pieces subjected to compression and flexural strength testing when reinforced using both types of fabric, which suggests that the rigidity of the casing plays a secondary role. In order to delve into this topic, it would be necessary to carry out another experimental campaign similar to the one used in this work, but also using other types of fibers that, while maintaining approximately the same mechanical capacity, offer a significant range of stiffness.

Author Contributions: Conceptualization, D.B.V., M.d.l.N.G.G. and A.C.E.; methodology, M.d.l.N.G.G. and A.C.E.; validation, M.d.I.N.G.G. and A.C.E.; formal analysis, D.B.V., M.d.I.N.G.G. and A.C.E.; investigation, D.B.V.; resources, D.B.V.; data curation, D.B.V.; writing-original draft preparation, M.d.I.N.G.G. and A.C.E.; writing-review and editing, D.B.V. and M.d.1.N.G.G.; supervision, M.d.I.N.G.G. All authors have read and agreed to the published version of the manuscript.

Funding: This research received no external funding.

Institutional Review Board Statement: Not applicable.

Informed Consent Statement: Not applicable.

Data Availability Statement: Data available on request. The data are not publicly available because they belong to a Doctoral Thesis that has not yet been defended.

Conflicts of Interest: The authors declare no conflict of interest.

\section{References}

1. El Maaddawy, T. Strengthening of eccentrically loaded reinforced concrete columns with fiber-reinforced polymer wrapping system: Experimental investigation and analytical modeling. J. Compos. Constr. 2009, 13, 13-24. [CrossRef]

2. Pendhari, S.S.; Kant, T.; Desai, Y.M. Application of polymer composites in civil construction: A general review. Compos. Struct. 2008, 24, 84-114. [CrossRef]

3. Wolff, R.; Miessles, H. HLV-spannglieder in der praxis. Erfahrungen mit glasfaserverbundstaeben. Beton 1989, 2, 2-39. 
4. Meier, U. Bridge repair with high performance composite materials. Mater. Tech. 1987, 4, 125-128.

5. Rostasy, F. Bonding of steel and GFRP plates in the area of coupling joints. In Talbrucke Kattenbusch; Research Report, 3126/1429; Federal Institute for Materials Testing: Braunschweig, Germany, 1987.

6. Bank, L.C. Composites for Construction: Structural Design with FRP Materials; John Wiley \& Sons: New York, NY, USA, 2006; 560p.

7. Zeng, J.J.; Lin, G.; Teng, J.G.; Li, L.J. Behavior of large-scale FRP-confined rectangular RC columns under axial compression. Eng. Struct. 2018, 174, 629-645. [CrossRef]

8. Chavla, K.K. Composite materials 1980: A report on the 3rd International Conference on composite materials, Paris, August 26-29, 1980. Mater. Sci. Eng. 1981, 48, 137-141. [CrossRef]

9. Baker, A.A. Advanced Fibre Composites for Aerospace Applications-Conference on New Materials and Processes for Mechanical Design; Institution of Engineers: Brisbane, Australia, 1988; pp. 69-76.

10. Chawla, K.K. Composite Materials Science and Engineering, 3rd ed.; Springer: New York, NY, USA, 1998. [CrossRef]

11. Feldman, D. (Ed.) Polymeric Building Materials, 1st ed.; Routledge: London, UK, 1989. [CrossRef]

12. Meier, U.; Deuring, M.; Meier, H.; Schwegler, G. Strengthening of Structures with CFRP Laminates: Research and Applications in Switzerland. In Proceedings of the Advanced Composite Materials in Bridges and Structures, ACMBS/MCAPC 1st International Conference, Sherbrooke, QC, Canada, 18-20 August 1992.

13. Ritchie, P.; Thomas, D.; Lu, L.; Conneley, G. External reinforcement of concrete beams using fiber reinforced plastics. ACI Struct. J. 1991, 88, 490-500. [CrossRef]

14. Sharif, A.; Al-Sulaimani, G.J.; Basunbul, I.A.; Baluch, M.H.; Ghaleb, B.N. Strengthening of initially loaded reinforced concrete beams using FRP plates. ACI Struct. J. 1994, 91, 160-168. [CrossRef]

15. Triantafillou, T.C.; Antonopoulos, C.P. Design of concrete flexural members strengthened in shear with FRP. J. Compos. Constr. 2000, 4, 198-205. [CrossRef]

16. Khalifa, A.; Nanni, A. Improving shear capacity of existing RC T-section beams using CFRP composites. Cem. Concr. Compos. 2000, 22, 165-174. [CrossRef]

17. Täljsten, B.; Elfgren, L. Strengthening concrete beams for shear using CFRP-materials: Evaluation of different application methods. Compos. Part B Eng. 2000, 31, 87-96. [CrossRef]

18. Täljsten, B. Strengthening concrete beams for shear with CFRP sheets. Constr. Build. Mater. 2003, 17, 15-26. [CrossRef]

19. Teng, J.G.; Chen, J.F.; Smith, S.T.; Lam, L. FRP: Strengthened RC Structures; John Wiley \& Sons: Hoboken, NJ, USA, 2001.

20. Budvytis, M.; Cobo, A.; Juknevičius, L. Analysis of shear design recommendations for FRP reinforced concrete beams. Eng. Struct. Technol. 2018, 10, 46-57. [CrossRef]

21. Obaidat, Y.T.; Ashteyat, A.M.; Obaidat, A.T. Performance of RC beam strengthened with NSM-CFRP. Strip under pure torsion: Experimental and numerical study. Int. J. Civ. Eng. 2020, 18, 585-593. [CrossRef]

22. FIB Bulletin 14. Externally bonded FRP Reinforcement for RC structures. Design and use of externally bonded fibre reinforced polymer reinforcement (FRP EBR) for reinforced concrete structures. Tech. Rep. Int. Fed. Struct. Concr. 2001, 14, 51-58.

23. ACI 440.2 R-17; Guide for the Design and Construction of Externally Bonded FRP Systems for Trengthening Concrete Structures; American Concrete Institute: Farmington Hills, MI, USA, 2017.

24. Concrete Society Technical Report; Design Guidance for Strengthening Concrete Structures Using Fibre Composite Materials; Concrete Society: Camberley, UK, 2012; p. 55.

25. CNR (National Research Council). Guide for the Design and Construction of Externally Bonded FRP Systems for Strengthening Existing Structures; CNR: Roma, Italy, 2013; pp. 1-154.

26. CSA S806-2012 (R2017); Design and Construction of Building Structures with Fibre-Reinforced Polymers; Reaffirmed 2017; Canadian Standards Association: Toronto, ON, Canada, 2012.

27. ACI 318-19; Building Code Requirements for Structural Concrete; American Concrete Institute: Farmington Hills, MI, USA, 2019.

28. Schlaich, J.; Schafer, K.; Jennewein, M. Toward a consistent design of structural concrete. PCI J. 1987, 32, 74-150. [CrossRef]

29. Campione, G. Load carrying capacity of RC compressed columns strengthened with steel angles and strips. Eng. Struct. 2012, 40, 457-465. [CrossRef]

30. Adam, J.M.; Ivorra, S.; Giménez, E.; Moragues, J.J.; Miguel, P.; Miragall, C.; Calderón, P.A. Behaviour of axially loaded RC columns strengthened by steel angles and strips. Steel Compos. Struct. 2007, 7, 405-419. [CrossRef]

31. Braga, F.; Gigliotti, R.; Laterza, M. Analytical stress-strain relationship for concrete confined by steel stirrups and/or FRP jackets. J. Struct. Eng. 2006, 132, 1402-1416. [CrossRef]

32. Cirtek, L. RC columns strengthened with bandage-Experimental programme and design recommendations. Constr. Build. Mater. 2001, 15, 341-349. [CrossRef]

33. Zhang, S.; Liu, J. Seismic behavior and strength of square tube confined reinforced-concrete (STRC) columns. J. Constr. Steel Res. 2007, 63, 1194-1207. [CrossRef]

34. Fam, A.; Qie, F.S.; Rizkalla, S. Concrete-filled steel tubes subjected to axial compression and lateral cyclic loads. J. Struct. Eng. 2004, 130, 631-640. [CrossRef]

35. McAteer, P.; Bonacci, J.F.; Lachemi, M. Composite response of high-strength concrete confined by circular steel tube. Struct. J. 2004, 101, 466-474. [CrossRef]

36. Zhang, S.; Guo, L.; Ye, Z.; Wang, Y. Behavior of steel tube and confined concrete high strength concrete for concrete-filled RHS tubes. Adv. Struct. Eng. 2005, 8, 101-116. [CrossRef] 
37. Fardis, M.N.; Khalili, H. Concrete encased in fiberglass-reinforced plastic. J. Proc. 1981, 78, 440-446.

38. Katsumata, H.; Kobatake, Y.; Takeda, T. A study on the strengthening with carbon fiber for earthquake-resistant capacity of existing reinforced concrete columns. In Proceedings of the Ninth World Conference on Earthquake Engineering, Tokyo, Japan, 2-9 August 1988; pp. 1816-1823.

39. Nanni, A. Concrete repair with externally bonded FRP reinforcement. Concr. Int. 1995, 17, 22-26.

40. Toutanji, H. Stress-strain characteristics of concrete columns externally confined with advanced fiber composites sheets. ACI Mater. J. 1999, 96, 397-404. [CrossRef]

41. Nanni, A.; Norris, M.S.; Bradford, N.M. Lateral confinement of concrete using FRP reinforcement. Spec. Publ. 1993, 138, 193-210.

42. Larralde, J. Compressive strength of small concrete specimens confined with fiberglass laminates. Cem. Concr. Aggreg. 1997, 19, 17-21. [CrossRef]

43. Saafi, M.; Toutanji, H.; Li, Z. Behavior of concrete columns confined with fiber reinforced polymer tubes. ACI Mater. J. 1999, 96, 500-509. [CrossRef]

44. Csuka, B.; Kollár, L.P. FRP-confined circular concrete columns subjected to concentric loading. J. Reinf. Plast. Compos. 2010, 29, 3504-3520. [CrossRef]

45. Aire, C.; Gettu, R.; Casas, J.; Marques, S.; Marques, D. Concrete laterally confined with fibre-reinforced polymers (FRP): Experimental study and theoretical model. Mater. Constr. 2010, 60, 19-31. [CrossRef]

46. de Diego, A.; Arteaga, A.; Fernández, J.; Perera, R.; Cisneros, D. Behaviour of FRP confined concrete in square columns. Mater. Constr. 2015, 65. [CrossRef]

47. Mazzucco, G.; Salomoni, V.A.; Majorana, C.E.; Pellegrino, C.; Ceccato, C. Numerical investigation of concrete columns with external FRP jackets subjected to axial loads. Constr. Build. Mater. 2016, 111, 590-599. [CrossRef]

48. Zeng, J.J.; Guo, Y.C.; Gao, W.Y.; Li, J.Z.; Xie, J.H. Behavior of partially and fully FRP-confined circularized square columns under axial compression. Constr. Build. Mater. 2017, 152, 319-332. [CrossRef]

49. Triantafyllou, G.G.; Rousakis, T.C.; Karabinis, A.I. Axially loaded reinforced concrete columns with a square section partially confined by light GFRP straps. J. Compos. Constr 2015, 19, 04014035. [CrossRef]

50. Csuka, B.; Kollár, L.P. Analysis of FRP confined columns under eccentric loading. Compos. Struct. 2012, 94, 1106-1116. [CrossRef]

51. Daugevičius, M.; Valivonis, J.; Beinaravičius, A.; Skuturna, T.; Budvytis, M. Experimental investigation of the load carrying capacity of eccentrically loaded reinforced concrete elements strengthened with CFRP. Procedia Eng. 2013, 57, 232-237. [CrossRef]

52. Harmon, T.G.; Ramakrishnan, S.; Wang, E.H. Confined concrete subjected to uniaxial monotonic loading. J. Eng. Mech. 1998, 124, 1303-1309. [CrossRef]

53. Li, Q.; Ansari, F. High-strength concrete in triaxial compression by different sizes of specimens. ACI Mater. J. 2000, 97, 684-689. [CrossRef]

54. Almusallam, T.H. Behavior of normal and high-strength concrete cylinders confined with E-glass/epoxy composite laminates. Compos. Part B Eng. 2007, 38, 629-639. [CrossRef]

55. Micelli, F.; Modarelli, R. Experimental and analytical study on properties affecting the behaviour of FRP-confined concrete. Compos. Part B Eng. 2013, 45, 1420-1431. [CrossRef]

56. Vincent, T.; Ozbakkaloglu, T. Influence of concrete strength and confinement method on axial compressive behavior of FRP confined high- and ultra high-strength concrete. Compos. Part B Eng. 2013, 50, 413-428. [CrossRef]

57. Lam, L.; Teng, J.G. Stress-strain model for FRP-confined concrete under cyclic axial compression. Eng. Struct. 2009, 31, 308-321. [CrossRef]

58. Isleem, H.F.; Wang, D.; Wang, Z. Modeling the axial compressive stress-strain behavior of CFRP-confined rectangular RC columns under monotonic and cyclic loading. Compos. Struct. 2018, 185, 229-240. [CrossRef]

59. Wang, D.; Wang, Z.; Yu, T.; Li, H. Seismic performance of CFRP-retrofitted large-scale rectangular RC columns under lateral loading in different directions. Compos. Struct. 2018, 192, 475-488. [CrossRef]

60. Fernández-Cánovas, M.; González-García, M.; Piñero, J.; Cobo, A. Compressive strength behaviour of low- and medium-strength concrete specimens confined with carbon fibres in defective implementation conditions: An experimental study. Mater. Constr. 2016, 66, e103. [CrossRef]

61. Micelli, F.; Cascardi, A.; Aiello, M.A. A study on FRP-confined concrete in presence of different preload levels. In Proceedings of the 9th International Conference on Fibre-Reinforced Polymer (FRP) Composites in Civil Engineering-CICE, Paris, France, 17-19 July 2018; pp. 17-19.

62. Richart, F.E.; Brandtzæg, A.; Brown, R.L. A Study of the Failure of Concrete under Combined Compressive Stresses; University of Illinois at Urbana-Champaign, College of Engineering, Engineering Experiment Station: Champaign, IL, USA, 1928.

63. Richart, F.E.; Brandtzæg, A.; Brown, R.L. Failure of Plain and Spirally Reinforced Concrete in Compression; University of Illinois at Urbana Champaign, College of Engineering, Engineering Experiment Station: Champaign, IL, USA, 1929.

64. Mander, J.B.; Priestley, M.J.; Park, R. Theoretical stress-strain model for confined concrete. J. Struct. Eng. 1988, 114, 1804-1826. [CrossRef]

65. Ozbakkaloglu, T.; Lim, J.C.; Vincent, T. FRP-confined concrete in circular sections: Review and assessment of stress-strain models. Eng. Struct. 2013, 49, 1068-1088. [CrossRef]

66. Ozbakkaloglu, T.; Lim, J.C. Axial compressive behavior of FRP-confined concrete: Experimental test database and a new design-oriented model. Compos. Part B Eng. 2013, 55, 607-634. [CrossRef] 
67. Teng, J.G.; Lu, X.Z.; Ye, L.P.; Jiang, J.J. Recent research on intermediate crack induced debonding in FRP strengthening beams. In Proceedings of the 4th International Conference on Advanced Composite Materials for Bridges and Structures, Calgary, AB, Canada, 20-23 July 2004.

68. Teng, J.G.; Smith, S.T.; Yao, J.; Chen, J.F. Intermediate crack-induced debonding in RC beams and slabs. Constr. Build. Mater. 2003, 17, 447-462. [CrossRef]

69. NCh 170:2016; Hormigón—Requisitos Generales; Instituto Nacional de Normalización de Chile: Santiago, Chile, 2016.

70. NCh 1172:2010; Hormigón—Refrentado de Probetas; Instituto Nacional de Normalización de Chile: Santiago, Chile, 2010.

71. NCh 1037:1977; Hormigón—Ensayo de compresión de probetas cúbicas y cilíndricas; Instituto Nacional de Normalización de Chile: Santiago, Chile, 1977.

72. Xiao, Y.; Wu, H. Compressive behavior of concrete confined by carbon fiber composite jackets. J. Mater. Civ. Eng. 2000, 12, 139-146. [CrossRef]

73. Lam, L.; Teng, J.G. Design-oriented stress-strain model for FRP-confined concrete. Constr. Build. Mater. 2003, 17, 471-489. [CrossRef]

74. Harries, K.A.; Carey, S.A. Shape and "gap" effects on the behavior of variably confined concrete. Cem. Concr. Res. 2003, 33, 881-890. [CrossRef]

75. Yang, X.; Nanni, A.; Chen, G. Effect of corner radius on the performance of externally bonded FRP reinforcement. In Proceedings of the 5th International Symposium on Fiber Reinforced Polymer for Reinforced Concrete Structures (FRPRCS-5), Cambridge, UK; London, UK, 16-18 July 2001; pp. 197-204. [CrossRef]

76. Berner, D.E.; Hoff, G.C. Headed reinforcement in disturbed strain regions of concrete members. Concr. Int. 1994, 16, 48-52.

77. Adebar, P.; Kuchma, D.; Collins, M.P. Strut-and-tie models for the design of pile caps: An experimental study. ACI Struct. J. 1990, $87,81-92$. 